\title{
Recent Increase of Nesting on Utility Poles by the Black-billed Magpie Pica pica sericea.
}

\author{
Kazuhiro EGUCHI \\ Department of Biology, Faculty of Science, Kyushu University 33, \\ Fukuoka 812-81, Japan.
}

\begin{abstract}
A study on the nest-site preference of the Black-billed Magpie Pica pica sericea was conducted in northeastern Saga City, northern Kyushu, Japan. In first nesting, the proportion of magpie nests on utility poles was significantly greater than expected from random nesting. However, the proportion of nests on utility poles in repeat nesting decreased in comparison to first nesting. Incomplete nests occurred more frequently in trees than on utility poles, suggesting that, if they selected trees, magpies carried nest material to more locations before settling on a suitable nest site. Pairs nesting on utility poles achieved higher nesting success than those nesting in trees. The percentage of complete magpie nests on utility poles increased from $41 \%$ in 1991 to $55 \%$ in 1994 . Nesting on utility poles may be among the possible reasons for the recent geographic expansion of magpies in Japan.
\end{abstract}

Key words: Black-billed Magpie, man-made structure, nesting success, nest-site preference, Pica pica sericea.

Nest-site selection is closely related to fitness in birds. Considerable variation exists among nest sites in types of qualities such as vulnerability to predation, exposure to inclement weather, and proximity to food resources. Because predation is the major cause of nesting failure (MARTIN 1992), it is important for birds to select safe nest sites. Nest concealment or inaccessibility to predators may enhance breeding success, but there have been conflicting conclusions among studies (e.g. Dunham 1990, Gawlik \& Bildstein 1990, Holway 1991, Laubhan \& Reid 1991, Kelly 1993, Norment 1993, Badyaev 1995).

The Black-billed Magpie Pica pica inhabits a variety of habitats ranging from open ground to urban locations (BIRKHEAD 1991). Magpies usually build their domed nests in trees; occasionally, they build nests on man-made structures such as utility poles, towers, and disused cranes (BIRKHEAD 1991, KAVANAGH et al. 1991). As well, studies have revealed that Black-billed Magpies prefer nesting trees with dense canopy, which presumably provides protection against both nest predation and bad weather (TATNER 1982, DHINDSA et al. 1989). However, no study investigating the relationship between nest-site quality and breeding success appears to have been conducted. In Japan, the Black-billed Magpie P. p. sericea inhabits a very restricted region in northern Kyushu, the southern major island. In this region, it has achieved relatively high nesting densities, exceeding 20 pairs per $\mathrm{km}^{2}$ in some areas (EGUCHI \& TAKEISHI 1996). This Black-billed Magpie builds its nests on the most available trees, apparently without preference for paticular 
species (TAKEISHI \& EGUCHI 1994). On the other hand, nesting on utility poles has increased in recent years (SAGA PREFECTURE 1990). The purpose of this study reported here was to investigate (1) whether magpies preferred utility poles to trees for nesting, and (2) whether nesting on utility poles was related to nesting success.

\section{STUDY AREA AND METHODS}

The study was conducted in northeastern Saga City $\left(33^{\circ} 18^{\prime} \mathrm{N}, 130^{\circ} 18^{\prime} \mathrm{E}\right)$, northern Kyushu, Japan. The study area comprised approximately $16 \mathrm{~km}^{2}$ of cultivated land, consisting entirely of paddy fields with scattered patches of human habitations. The elevation of this area ranges from $5 \mathrm{~m}$ to $20 \mathrm{~m}$. Nest density is moderate (13.8-19.5 nests per $\mathrm{km}^{2}$ between 1992 and 1994; EGUCHI \& TAKEISHI 1996).

This study consisted of three parts. First, during the period from 1989 to 1994, I examined the annual change in the proportion of nests built on utility poles. From March to May during these years, I searched for nests weekly, plotted them on a 1:5000-scale map, and recorded the substrate type (tree species or man-made structures) on which nests were placed. Magpies in the study area tended to breed at domed nests ("complete nests"), a finding that differed from studies of magpie populations elsewhere (cf. BIRKHEAD 1991). Undomed, or "incomplete nests" had no lining in them. It appeared likely that the undomed nests we observed were either in the process of being built or had actually been abandoned.

Second, I examined nesting success from 1992 to 1994 . I considered a nest to be successful if at least one chick fledged. Nests were checked weekly or bi-weekly to determine if chicks fledged. Some nests were checked by climbing (see EGUCHI 1995); other nests were checked from the ground. Because there was no statiscally significant difference in nesting success between nests checked by climbing and nests checked from the ground $\left(\chi^{2}=0.98, d f=1, P>0.10\right)$, the two categories were collapsed into the single category "nests in trees" for analysis.

Third, in order to examine preference for trees or utility poles in 1991 and 1993, I determined nest-site selection using suggestions from TATNER (1982). I chose 106 nests (76 nests in trees and 30 nests on utility poles) at random from the overall study area, avoiding concentration at particular places. I did not, however, allocate according to the proportion of both nest-site types. Within a $100 \mathrm{~m}$ radius of a nest, I recorded the nearest ten available nest sites (i.e., trees $5 \mathrm{~m}$ or higher and utility poles including utility pylons). The average distance between nearest neighbor nests in a study by TAKEISHI (1993) was $78.5 \mathrm{~m}$ in high density areas and $161.2 \mathrm{~m}$ in low density areas. And, TAKEISHI \& EGUCHI (1994) found that magpies seldom nest in trees less than $8 \mathrm{~m}$ in hight. On the basis of these findings, the limitation in range and tree height for sampling nest-sites in this study seemed appropriate. If there were less than ten nest sites within $100 \mathrm{~m}$, all nest sites were counted. Because magpies avoid nesting in forests (SAGA Prefecture 1990, pers. obs.), I omitted from the study all nests adjacent to forests. All data were combined to calculate the availability of trees and utility poles.

Utility poles were distributed rather uniformly, while trees often showed a patchy distribution. This may have resulted in smaller number of utility poles around a given nest. It is possible, however, that combining data, by using the method described above for testing nest-site preference, may mask individual 
differences and cause overestimation of the preference for utility poles. Therefore, a second method for testing preference for nest sites was used. I assigned an individual nest as "preferred" if it differed in type from the majority of nest sites around it. For example, if a nest was built on a utility pole in an area where utility poles were fewer in number than were trees, the utility pole was identified as a "preferred" site. I summed the cases of "preferred" for each nest-site type, and then compared the proportion of "preferred" cases between utility pole and tree.

In this paper, data from first nests were used unless stated otherwise.

\section{RESULTS}

Nesting on utility poles has been increasing in the study area since 1991, according to data including incomplete nests (Fig. 1). The proportion of complete nests on utility poles was somewhat larger than that of all nests (both complete and incomplete) on utility poles. During the period $1991-1994$, the percentage of complete nests on utility poles increased from $41 \%$ to $55 \%$.

In total, 728 trees (80\%) and 186 utility poles (20\%) were recorded in the vicinity of the 106 randomly-selected nests in 1991 and 1993. These comprised the available nest sites in this study. Of the 439 nests in the study area, 231 (53\%) were located in trees and $208(47 \%)$ were located on utility poles. More nests were built on utility poles than would be expected if magpies nested at random (Table 1). Preference for nesting on utility poles was observed in both years $\left(\chi^{2}=101.9, d f=1\right.$ in 1991 and $\chi^{2}=103.8$,

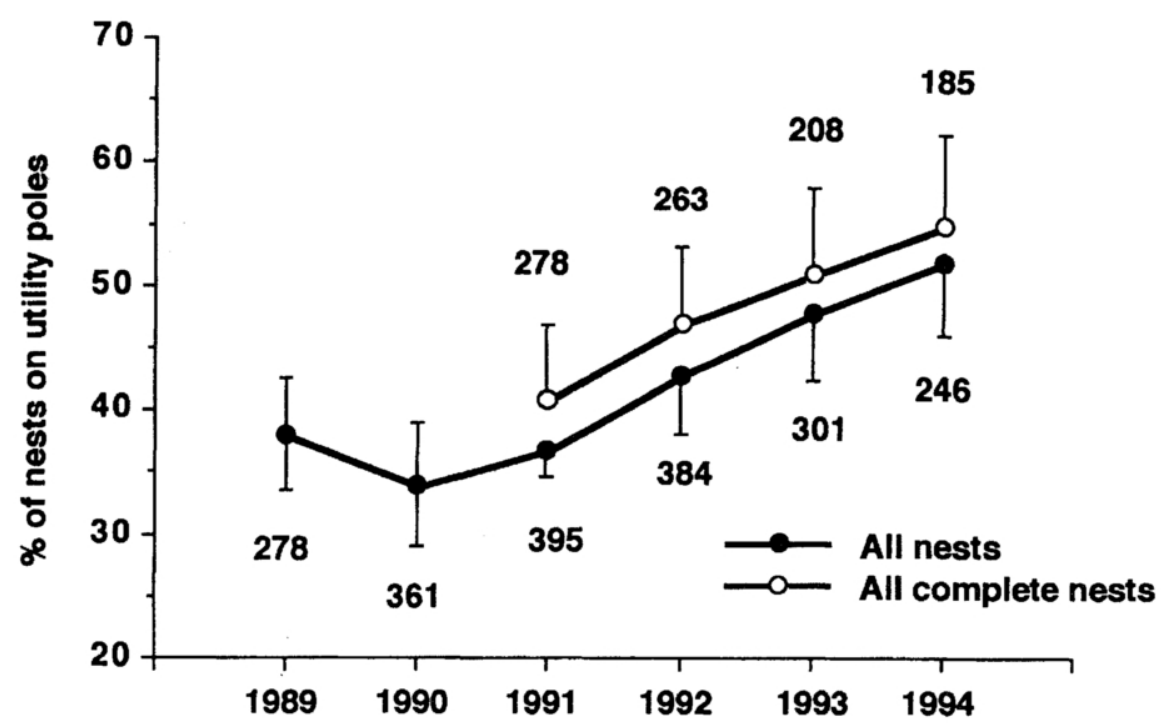

Fig. 1. Annual change in the proportion of the magpies' nests on utility poles. Figures are the number of nests examined (including repeat nests), and vertical bars indicate $95 \%$ confidence limits based on the binomial distribution. In 1989 and 1990, I did not discriminate complete and incomplete nests on utility poles in the data set. 
Table 1. The preference for utility poles by nesting Black-billed Magpie. Data were combined for 1991 and 1993.

\begin{tabular}{lccccc}
\hline & \multicolumn{2}{c}{ Available nest-sites } & & \multicolumn{2}{c}{ Number of nests } \\
\cline { 2 - 3 } \cline { 6 - 6 } & No. of nests-sites & Proportion & & Observed & Expected \\
\hline Trees & 728 & 0.80 & & $231(53 \%)$ & 351 \\
Utility poles & 186 & 0.20 & & $208(47 \%)$ & 88 \\
\hline Total & 914 & 1.00 & & 439 & 439 \\
\hline
\end{tabular}

*The number of complete first nests built in 1991 and 1993. The proportion of nests on utility poles was significantly greater than expected $\left(\chi^{2}=204.7, d f\right.$ $=1, P<0.0001$ ).

$d f=1$ in 1993; $P<0.0001$ in both cases).

Among the 106 nests examined, 19 of 30 nests on utility poles and 7 of 76 nests in trees were assigned as "preferred". The proportion of "preferred" cases was significantly higher in nests on utility poles than in those in trees $\left(\chi^{2}=31.18, d f\right.$ $=1, P<0.001$ ). From 1992 to 1994, 67 pairs rebuilt nests near their first nests after breeding failure. In repeat nesting, 79\% (22 of 28) of pairs who had built their first nests on utility poles changed nest-site type, while 28\% (11 of 39) of pairs who had nested in trees did so. A significantly higher proportion of pairs

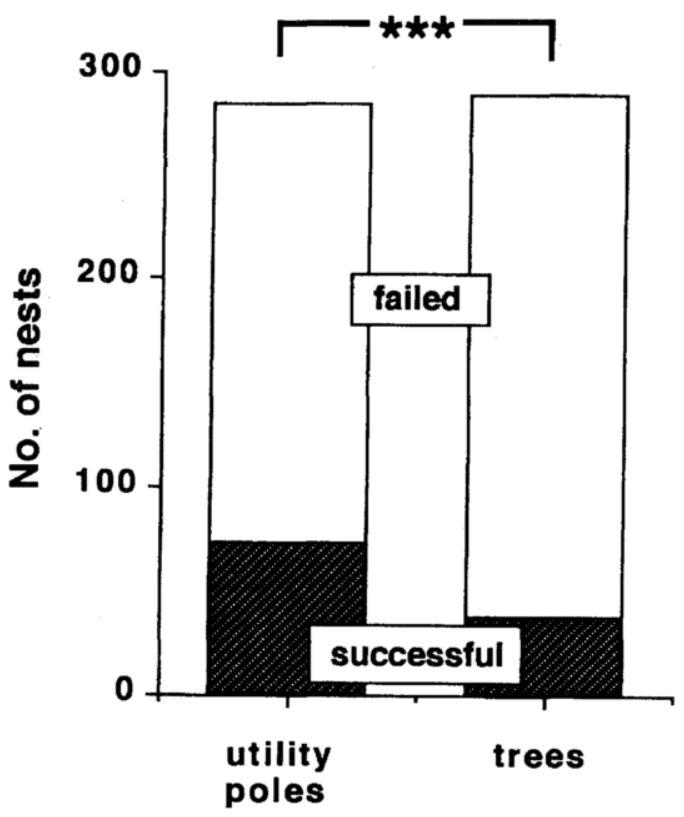

Fig. 2. The proportion of successful Black-billed Magpie nests on utility poles and those in trees. The number of nests checked is 284 and 288 for utility pole and tree, respectively. Data were combined for the three years from 1992 to $1994\left(\chi^{2}=12.836, d f=1, P<0.001, \chi^{2}\right.$-test $)$ 
who initially built nests on utility poles changed nest-site type in their repeat nesting ( $\left.\chi^{2}=14.59, d f=1, P<0.001\right)$. Thus, of the 67 new nests, 17 nests $(25 \%)$ were on utility poles and $50(75 \%)$ were in trees.

The percentage of incomplete nests was $32 \%, 31 \%$ and $25 \%$ of all nests built in 1992, 1993 and 1994, respectively. The proportion of incomplete nests was significantly lower on utility poles than in trees: 105 of 436 (24\%) nests on utility poles and 170 of $495(34 \%)$ nests in trees $\left(\chi^{2}=6.08, d f=1, P<0.05\right)$.

Overall nesting success was very low; only 19\% (110 of 572) of the total number of complete nests checked were successful during the period from 1992 to 1994. Nesting success, however, was significantly higher on utility poles than in trees $\left(\chi^{2}=12.84, d f=1, P<0.001 ;\right.$ Fig. 2).

\section{DISCUSSION}

Magpies preferred utility poles to trees for nesting and experienced a higher nesting success on utility poles than in trees. In northern Saga City, predation accounts for more than $80 \%$ of nesting failure, major predators being Corvus crows and, in some cases, ground predators such as domestic cats Felis catus, Siberian weasels Mustela sibirica and snakes Elaphe climacophora (EGUCHI 1995). A nest on a utility pole made of concrete may be free from mammalian predators because of the pole's smooth surface, thus contributing to the higher nesting success. Moreover, nests on utility poles are probably easier to defend from crows than those in trees. Crows that approached nests on utility poles were of ten attacked and struck by magpies, which to some extent was an effective behavior. On the other hand, bulky branches prevented magpies defending nests in trees from attacking nest predators. Surrounded by thick foliage, magpies only uttered alarm calls or showed displacement behaviour, such as pecking on a branch.

With magpies, as with other birds, it has been claimed that nest concealment is an important factor in nest-site selection (DHINDSA et al. 1989, Holway 1991, Kelly 1993, Norment 1993, Badyaev 1995). Nest visibility, however, was much higher on utility poles than in trees, particularly after mid-April when deciduous trees leafed out. Nevertheless, utility poles were the preferred nesting sites. Hence, nest concealment did not appear to influence nest-site preference of Japanese magpies, in contrast to Canadian magpies (DHINDSA et al. 1989). This assumption is supported by the fact that magpies did not prefer evergreen trees, even though they offered higher concealment than did deciduous trees (TAKEISHI \& EGUCHI 1994).

Magpies prefer utility poles for nesting probably because of the higher nesting success. In addition, uniformity in structure among poles may also facilitate this preference. A tree has a more complicated structure than a utility pole and has great variations in quality for nest-site location, not only among different places in a tree but also among different trees. Therefore, it would appear to be more difficult for magpies to find suitable places for nesting in trees than on a utility pole. Because more incomplete nests were built in trees than on utility poles, a pair presumably had to bring nest materials to several trees before finally finding a suitable nest site. As a consequence, it is likely that more time is necessary to complete a nest when a tree is selected for nesting rather than a utility pole.

Despite the higher nesting success with utility poles, pairs that failed in their 
first nesting did not always prefer to nest on utility poles in repeat nesting. The percentage of nests located on utility poles decreased in repeat nesting to about $25 \%$, close to the proportion of available utility poles, which suggests that they selected nests at random. Though nesting in trees was clearly less successful, the abundance of trees predicted the liklihood of their being more frequently chosen.

The increase of nest location on utility poles by magpies was seen throughout its range of distribution in Japan. For example, the percentage of magpie nests on utility poles was less than $10 \%$ in 1975 and increased to about $65 \%$ in 1989 (SAGA Prefecture 1990). Before the 1980s, the proportion of magpie nests on utility poles was low (Saga Prefecture 1990, H. Kubo pers. comm.). In those earlier years, the utility poles had only one crossarm, and thus were not suitable for nesting magpies to place nest materials on them. Nowadays, however, a utility pole has more crossarms and lines, and, accordingly, provides magpies with good nest-sites. Though magpies use large trees for nesting, they avoid large forests (SAga Prefecture 1990, pers. obs.), and these forests may act as a geographic barrier. Nesting on utility poles enabled magpies to expand not only to areas where large trees were scarce, as in the case of reclaimed lands, but also to areas where forests had been cleared for human habitation. Increased nesting on utility poles may be one of the reasons why the number of Japanese magpies has been increasing and their range has been expanding in recent years. However, even on utility poles nest predation was very high and the difference in depredation rates between nest-site types was not large. This likely accounts for the fact that the increase of nesting on utility poles was gradual.

I am very grateful to Hiromi Kubo and Masayoshi Takeishi for their invaluable assistance and helpful suggestions in this study. Hiroyoshi Higuchi, Hisashi Nagata, Navjot Singh Sodhi and Christopher J. Norment provided helpful comments on earlier drafts of the manuscript.

\section{LITERATURE CITED}

Badyaev, A. V., 1995. Nesting habitat and nestling success of Eastern Wild Turkeys in the Arkansas Ozark Highlands. Condor 97: 221-233.

Birkhead, T. R., 1991. The Magpies. Poyser, London.

Dhindsa, M. S., Komers, P. E., \& BoAG, D. A., 1989. Nest height of Black-billed Magpies: is it determined by human disturbance or habitat type? Can. J. Zool. 67: $228-232$.

Dunham. M. L., 1990. Nest-site selection by Boat-tailed Grackles. Wilson Bull. 102: 702-706.

EGUCHI, K., 1995. Seasonal change in breeding success of the Black-billed Magpie Pica pica sericea. Jap. J. Ornithol. 44: 73-80.

EgUchi , K., \& TAKeISHI , M., 1996. The ecology of the Black-billed Magpie in Japan. Acta Ornithologica 31 (in press)

Gawlik, D. A., \& Bildstein, K. L., 1990. Reproductive success and nesting habitat of Loggerhead Shrikes in north-central South Carolina. Wilson Bull. 102: 37-48.

Holway, D. A., 1991. Nest-site selection and the importance of nest concealment in the Black-throated Blue Warbler. Condor 93: 575-581.

Kavanagh, B. P., Jerzak, L., \& GoRski, W., 1991. Factors affecting the breeding performance of the Magpie (Pica pica) in three European cities. PinowskI, J., Kavanagh, B. P., \& Gorski, W. (eds.) Nestling mortality of graminivorous birds 
due to microorganisms and toxic substances, Pp. 71-81. Polish Scientific Publishers, Warsaw.

Kelly, J. P., 1993. The effect of nest predation on habitat selection by Dusky Flycatchers in limber pine-juniper woodland. Condor 95: 83-93.

Laubhan, M. K., \& Reid, F. A., 1991. Characteristics of Yellow-crowned Night Heron nests in lowland hardwood forests of Missouri. Wilson Bull. 103: 486-491.

MARTIN, T. E., 1992. Interaction of nest predation and food limitation in reproductive strategies. Power, D. M. (ed.) Current Ornithology. Vol. 9, Pp. 163-197. Plenum, New York.

NoRment, C. J., 1993. Nest-site characteristics and nest predation in Harris' Sparrows and White-crowned Sparrows in the Northwest Territories, Canada. Auk 110: 769-777.

Saga Preffecture., 1990. A report of the research on the ecology of the Black-billed Magpie in 1989. Pp. 27. Saga Prefecture, Saga. (in Japanese).

TAKEISHI, M., 1993. A study on the ecological factors in the population dynamics and distribution of the Black-billed Magpie Pica pica sericea in Japan. Unpublished Doctoral Thesis, Kyushu University.

TAKeishi, M., \& Eguchi, K., 1994. Nest-site characteristics in the Black-billed Magpies Pica pica sericea. Jap. J. Ornithol. 42: 53-60.

TAtner, P., 1982. Factors influencing the distribution of magpies Pica pica in an urban environment. Bird Study 29: 227-234.

(Accepted 15 July 1996) 
きに調査した。なお，ひとつの人工巣のなかの 2 つの偽卵のうちひとつであ捕食されていれば，その 人工巣は捕食されたあのとした。続いて，鍋田干拓地全体を一辺 $100 \mathrm{~m}$ のグリッドに区切り，ヶリの 巣が存在するグリッドをケリの防衛エリアと仮定して, そのエリア内にある人工巣の残存数, ハシボ ソガラスの侵入数を求めた。ここでは, 「侵入」とは八シボソガラスが防衛エリア内の地面に降りて いる場合と定義した。

その結果, 人工巣の残存率は, ケリの繁殖ステージを経るにつれて高くなり, 24 時間後の残存率で はステージ間で有意な差がみられた $(P<0.001)$ 。このことは, ケリが縄張りを形成し, 営巣, 繁殖 することで捕食者を追い払う防衛行動が活発になり，その結果人工巣全体の残存率を上昇させたもの と思われる。さらに, 防衛エリア内の人工巣の残存数も同様に, 繁殖ステージを経るにつれて增加し, 上記の結果を支持した。また, 防衛エリアへのハシボソガラスの侵入数は繁殖ステージを経るにつれ て減少する傾向が認められた $(P<0.05)$ 。

これらの結果から, ケリの営巣, 繁殖, および縄張り防衛が, 八シボソガラスの捕食行動に何らか の影響を及ぼし，その捕食機会を減じていることが示唆された。

\section{カササギによる電柱営巣の増加}

(Recent Increase of Nesting on Utility Poles by the

Black-billed Magpie Pica pica sericea. 45 : 101-107)

\section{江口 和洋}

九州大学理学部生物学教室

T812-81＼cjkstart福岡市東区箱崎6-10-1

佐賀市北東部のカササギ生息地において，カササギの電柱営巣の実態と電柱に対する選好性につい て調査を行った. 電柱営巣は最近増加傾向にあり, 完成巣に占める電柱巣の割合は 1991 年の $41 \%$ に対 して, 1994年は55\%であった。この傾向はカササギの分布域の広い範囲でみられている。

1991年と1993年にカササギの営巣場所選択の調査を行った．任意に巣を選び出し，巣を中心に 100 $\mathrm{m}$ 以内にある高さ $5 \mathrm{~m}$ 以上の樹木と電柱や鉄塔などの人工構造物のうち单に近い方から 10 ケ所の営 巣可能場所を記録した，選び出した106巣について，記録した営巣可能場所を合計し，電柱（20\%） と樹木（80\%）の割合を求めた。これらの值を両年の全完成巣に乗じた値をランダム営巣を仮定した 場合の期待值とした．電柱巣の割合は巣周辺の営巣可能場所に占める電柱の割合に応じてランダムに 選ばれるという仮定から期待されるよりも有意に大きかった（電柱巣：樹木巣 $=47 \%: 53 \% ; \chi^{2}$ $=204.7, d f=1, P<0.0001)$. また, 各巣について, 周辺の営巣可能場所のうち樹木と電柱の両営巣 場所タイプのどちらか数の少ない方のタイプに営巣していた場合を，「選好された」と仮定して，各 タイプの巣毎に「選好された」場合の比率を計算した. 電柱の巣では 30 巣中19巣が「選好」にあたっ ていたが, 樹木巣では76巣中 7 巣のみであった $\left(\chi^{2}=31.18, d f=1, P<0.001\right)$. どちらの結果も, カササギがランダム営巣を仮定した場合よりあ電柱に営巣する傾向が高いことを示していた。 しかし, 繁殖に失敗した場合のやり直し営巣では, 電柱に営巣した番の $79 \%$ が樹木に転換し，一方，樹木に営 巣していた番では $28 \%$ のが電柱に換わった. その結果, やり直し営巣では電柱巣の割合はやり直し 巣全体の（67巣）の $25 \%$ に減少した（1992年～1994年のデータ）。この值は利用可能な営巣場所に占 める電柱の割合に近く, ランダムな営巣場所選択を示唆している.

作りかけのまま放棄される巣は樹木巣（全樹木巣の34\%；1992年～1994年のデー夕）の方で多く， 
電柱巣 $(24 \%)$ では少なかった $\left(\chi^{2}=6.08, d f=1, P<0.05\right)$.これは, 樹木を選んだ番は最終的に 一つの巣が完成するまでに, いくつかの樹木へ巣材を運ぶのに対して, 電柱巣では造巣が開始される と他の場所へ巣材を運ぶことが少ないことを示唆している.

少なくとも 1 個体のヒナを巣立たせ巣の割合は電柱巣（284巣中72巣；1992年～1994年のデータ） の方が樹木巣 (288巣中38巣) よりも有意に大きかった（ $\left.\chi^{2}=12.84, d f=1, P<0.001\right)$. このことか ら, 電柱に営巣した方が繁殖成功が高いといえる.この地域の繁殖失敗の主原因は捕食で, 繁殖失敗 の80\%以上を占める（EGUCHI 1995）。電柱巣では樹木巣に比べて捕食が少ないことが繁殖成功の違 いの理由であると思われる. また, 電柱巣は樹木巣に比べて非常に目立つことから, 宩の隠蔽度が営 巣場所の選択や繁殖成功にそれほど影響していないことを示唆している.

電柱営巣はカササギの分布域の広い範用で增加傾向にあり, 分布域自体屯最近では拡大の傾向にあ る. 電柱営巣は, 樹木の少ない地域や宅地開発のため森林が開かれた地域へのカササギの進出を可能 とし, 分布域を拡大する原因の一つになったものと考えられる。 